\title{
Spectral Analysis and Magnetic Modeling over Biu - Damboa, Northeastern Nigeria
}

\author{
${ }^{1}$ Chinwuko, A. I., ${ }^{1}$ Onwuemesi, A. G., ${ }^{1}$ Anakwuba, E. K., ${ }^{1}$ Okeke, H. C., \\ ${ }^{2}$ Onuba L. N., Okonkwo, C.C. ${ }^{3}$ Ikumbur, E. B. ${ }^{4}$ \\ ${ }^{1}$ Department Of Geological Sciences, NnamdiAzikiwe University, Awka, Anambra State, Nigeria \\ ${ }^{2}$ Department of Geology, Anambra State University, Uli, Anambra State, Nigeria \\ ${ }^{3}$ Department of Physics, Federal College of Education (Technical) Umunze, Nigeria ${ }^{4}$ Department of Geology, \\ Benue State Polytechnic Ugbokolo,
}

\begin{abstract}
Four aeromagnetic maps between longitudes $12^{\circ} 00^{l}$ to $13^{\circ} 00^{l}$ E, and latitudes $10^{\circ} 30^{l}$ to $11^{\circ} 30^{l} \mathrm{~N}$, representing parts of southern Chad Basin and Upper Benue Trough have been assembled and subjected to spectral analysis and $2.0 \mathrm{D}$ modeling. The study will provide the depth of magnetic sources, basement structural trend, and nature of intrusive bodies in the basin amongst other things. The map is dominated by an elongated NE-SW magnetic low anomaly that stretches over a $20 \mathrm{~km}$ distance. A negative anomaly of about 160nT near Chibuk suggests a sediment thickness of $2.27 \mathrm{~km}$ extending northeast. $2.0 \mathrm{D}$ modeling along three profiles shows that the anomalies are caused by predominantly mafic rocks within the depth range of 0.67-2.27 $\mathrm{km}$. The presence of large and continuous bodies of mafic rocks indicated by these results suggests that the area is an old rift, affected by the activity of a mantle plume that gave rise to the mafic intrusions.
\end{abstract}

Keywords:Aeromagnetic survey, residual anomaly, spectral analysis, Chad Basin and Upper Benue Trough.

\section{Introduction}

The study area is located between longitudes $12^{\circ} 00^{1}$ to $13^{\circ} 00^{1} \mathrm{E}$, and latitudes $10^{\circ} 30^{1}$ to $11^{\circ} 30^{l} \mathrm{~N}$, covering part of the Upper Benue Trough and Southern Chad Basin, Nigeria. It is situated in the transitional zone within the West-Central African Rift Systems (WCARS) [1]. The Gongola arm of the upper Benue Trough (Fig. 1) is an N-S trending arm of the $1000 \mathrm{~km}$ long Benue Trough. The Benue Trough which ranges in width from 80 to $250 \mathrm{~km}$ [2], is an intraplate NE-SW rift, related to the opening of South Atlantic in the equatorial region [2,3]. This late Jurassic-Early Cretaceous to megastructure is filled with continental and marine sediments (up to $6500 \mathrm{~m}$ thick). Mesozoic to Cenozoicmagmatism has accompanied the evolution of the tectonic rift as it is scattered all over and throughout the Benue Trough [4].

Similarly, the Chad Basin is the largest area of inland drainage in Africa [5]. It occupies about 230,000 $\mathrm{km}^{2}$ in the Central Sahara and the southern Sudan [6]. About one tenth of the basin is situated in the northern part of Nigeria (Bornu Basin) where the western limit is formed by the water divide between the Niger and Chad drainage systems and the southern limit by the divide between the Chad and the Benue systems. Within Nigeria, the altitude of the basin falls from about $530 \mathrm{~m}$ at the western margin to about $300 \mathrm{~m}$ within the lake, along a distance of about $240 \mathrm{~km}$. This indicates a gentle slope towards Lake Chad. The generally low-lying topography is interrupted in the northern part by dunes which extend for many kilometers.

Aeromagnetic survey is one of the most important tools used in modern geological mapping. It is a rapid and cost effective technique for locating both hidden ores and structures associated with mineral deposits. Roughly about $60 \%$ of magnetic surveys are carried out for regional geological mapping and mineral exploration purposes while the remainder being mainly for petroleum exploration [7].

However, the present study is concerned with the interpretation of the aeromagnetic data over parts of the Upper Benue Trough and Southern Chad. The purpose of the study is to estimate the thickness of the sedimentary layer and the structural model for the magnetic sources within the study area using spectral analysis and 2.0 D modeling. These elements are discussed, taking into consideration the geological knowledge of the region and mean magnetic intensity. 


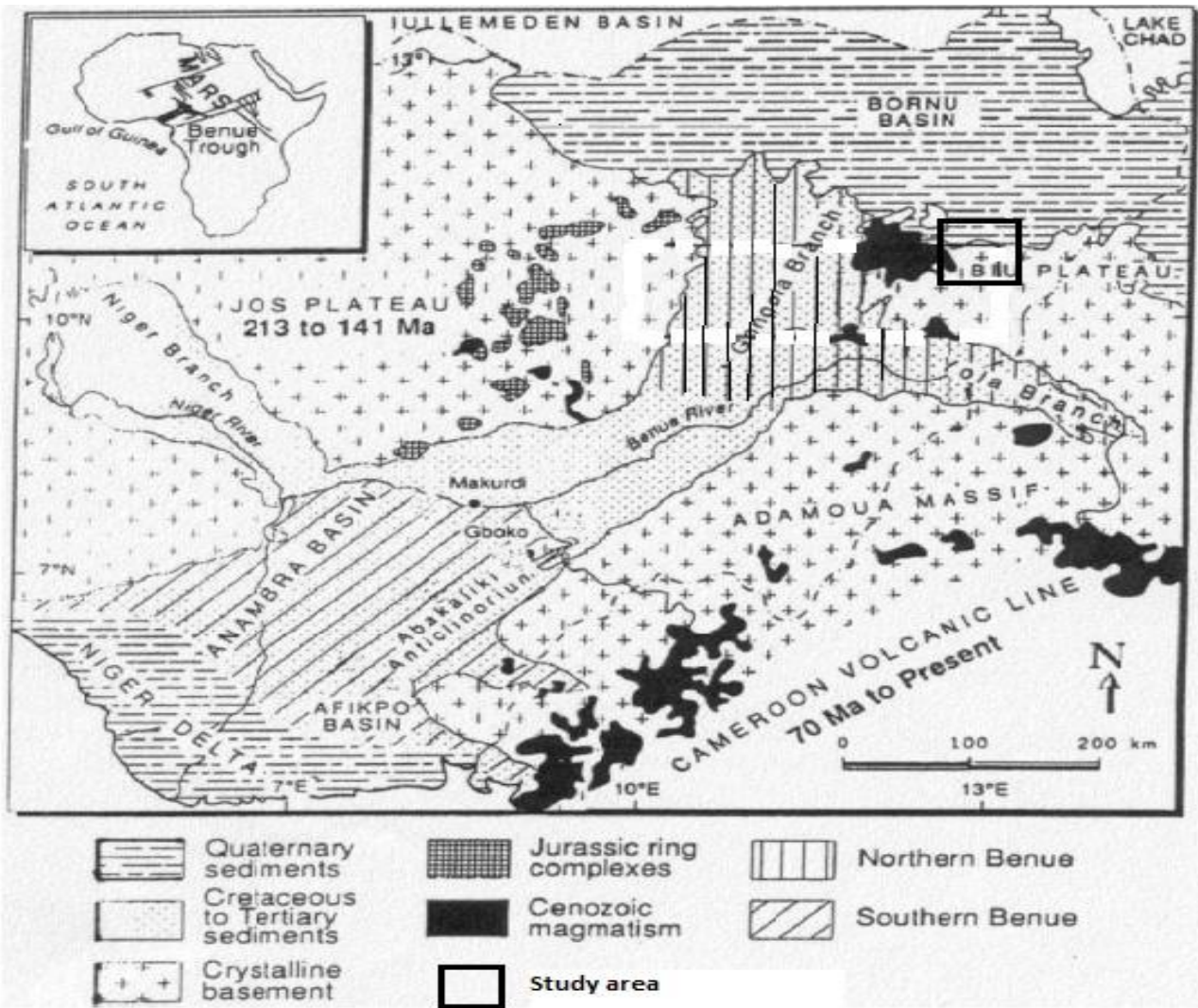

Fig.1: Geologic map of the study area (Adopted from [4])

\section{Regional Geology}

TheGongola arm of the Upper Benue Trough (Biu and Chibuk areas) is filled with Late Aptian toPalaeocene sediments(Fig.1). The basin is filled by fluvial/lacustrine sediments at the bottom, marine sedimentary units and then overlain by immature reddish continental sandstones at the top. The sedimentary rocks are underlain by a Precambrian to Palaeozoic basement complex, including gneisses and migmatitesandUpper Palaeozoic to Cambrian meta-sedimentary rocks. Mesozoic to Cenozoic (e.g. Tertiary Biu Basalts) igneous rocks are exposed in the study area.

For the Goniri and Damboa areas which are part of the Chad Basin; the origin of the Chad Basin as a sub-unit of the African interior cratonic basins is closely related to the separation of Gondwanaland in the Cretaceous. Several workers have proposed theories for the evolution of the Chad Basin $[1,8,9]$. The consensus among these workers is that the Chad Basin is the product of rifting, subsidence and sedimentation that accompanied the separation of the African and South American continental plates. Thus, three major sediment packages - the Bima Formations, Gongila-Fika Shale and the Chad Formations have been identified in the Nigerian sector of the Chad basin [10].

\section{Methodology}

The study commenced with the assemblage of four aeromagnetic mapsof the Geological Surveyof Nigeria. The original data were acquired using a total field proton precision magnetometer flown in an aircraft using a nominal flight height of $152.5 \mathrm{~m}$ above terrain, along NW-SE flight lines. Tie lines were also established $20 \mathrm{~km}$ apart. The regional correction applied was based on the IGRF (epoch date of 1st January1974).

The aeromagnetic maps were digitized at a regular spacing of $1 \mathrm{~km}$. Previous workers [11,12] wrote on crustal magnetic anomalies which suggest that this spacing is suitable for portrayal and interpretation of magnetic anomalies arising from regional crustal structure.

Digitization of data is followed by separation of aeromagnetic data. Here, a linear trend surface was fitted on to the digitized aeromagnetic data by a multiple regression technique for the purpose of removing the regional magnetic gradient. The linear surface so fitted was removed from the digitized data so as to obtain the residual anomaly data which was used to construct residual anomaly map. 
The data were then transformed into regular grid using computer software Surfur- 32 which iteratively carries out interpolation of data and contoured the anomalies (total magnetic field intensity and residual).

The residual anomaly was subjected to spectral analysis and 2.0 D modeling. Spectral analysis has been widely used by several authors $[13,14,15,16,17,18]$ to determine the depths of magnetic anomalies. Energy spectral analysis provides a technique for quantitative studies of large and complex aeromagnetic data sets. The logarithm of the radial average of the energy spectrum is plotted against the radial frequency. The slope of each segment provides information about the depth to the top of an ensemble of magnetic or gravity bodies [19].

\subsection{Aeromagnetic Anomalies}

\section{Results And Discussion}

The maps of the total magnetic field intensity and residual magnetic anomalies of the study area are shown in Figs. 2 and 3. Thefigures show that the total magnetic field and residual anomalies range from 6240 to $8400 \mathrm{nT}$ and -210 to $140 \mathrm{nTrespectively.}$

The most prominent features from the study area are found in Biu and Damboa; they are NE-SW trending axial magnetic anomaly, which stretch for more than $20 \mathrm{~km}$ and extending from Biu to the southwest and towards Damboa in the northeast (Figs. 2 and 4). A second anomaly parallel to the major magnetic lineament occurs around Chibuk and the third anomaly parallel to the major magnetic lineament occurs around Goniri.

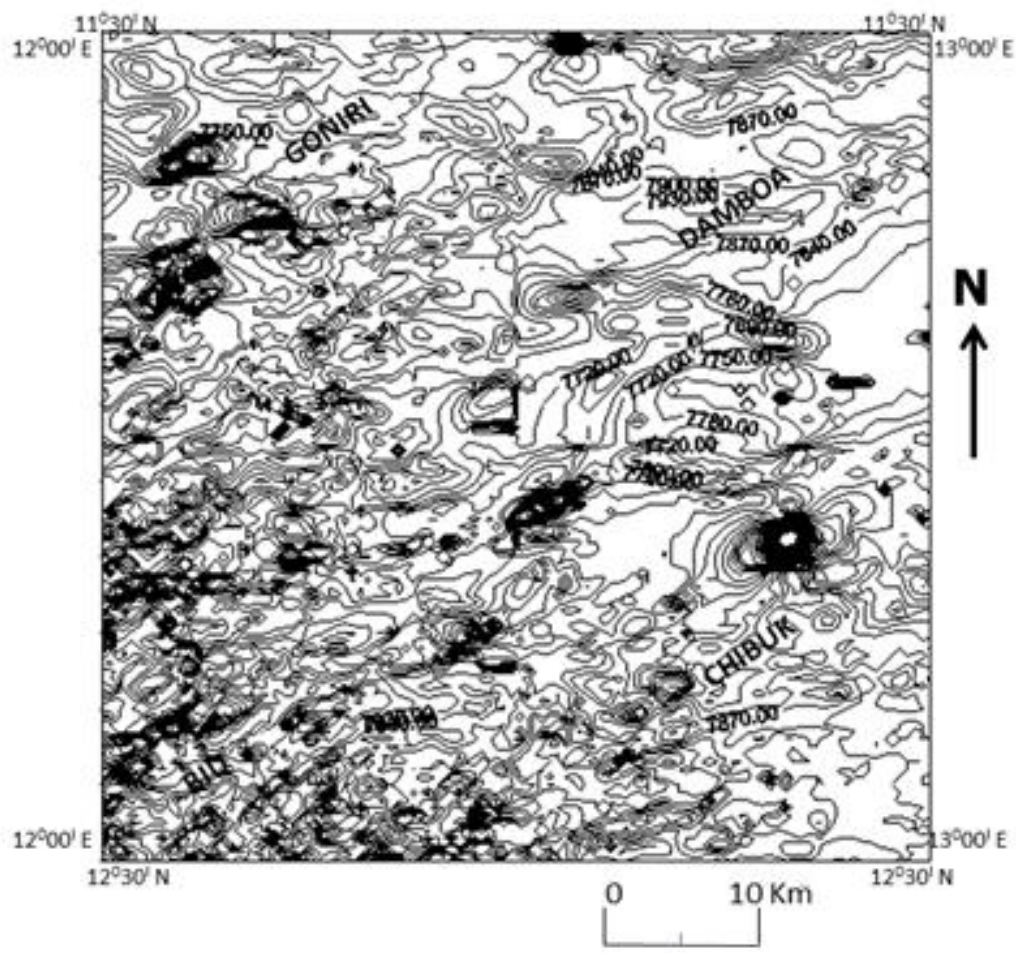

Figure 2: Total magnetic field intensity map (Contour Interval 30nT) 


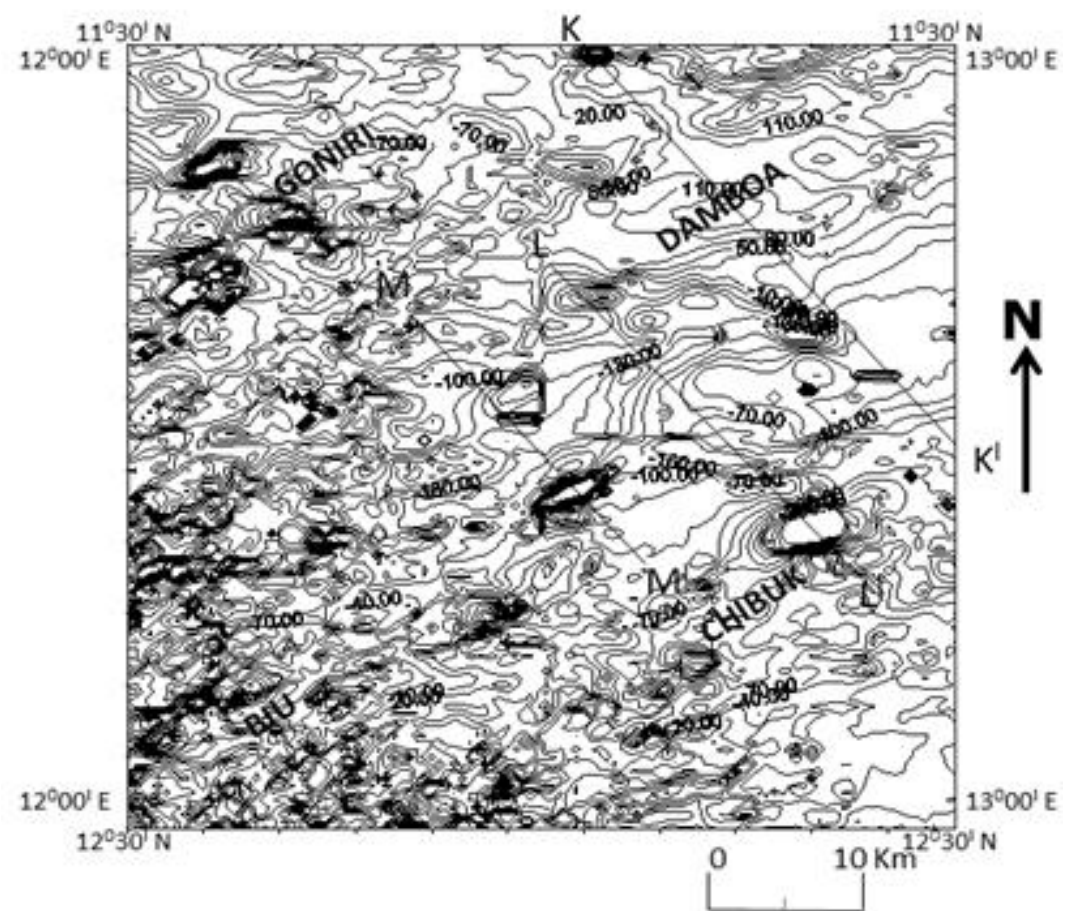

Figure 3: Residual anomaly map showing three profiles (Contour Interval 30nT)

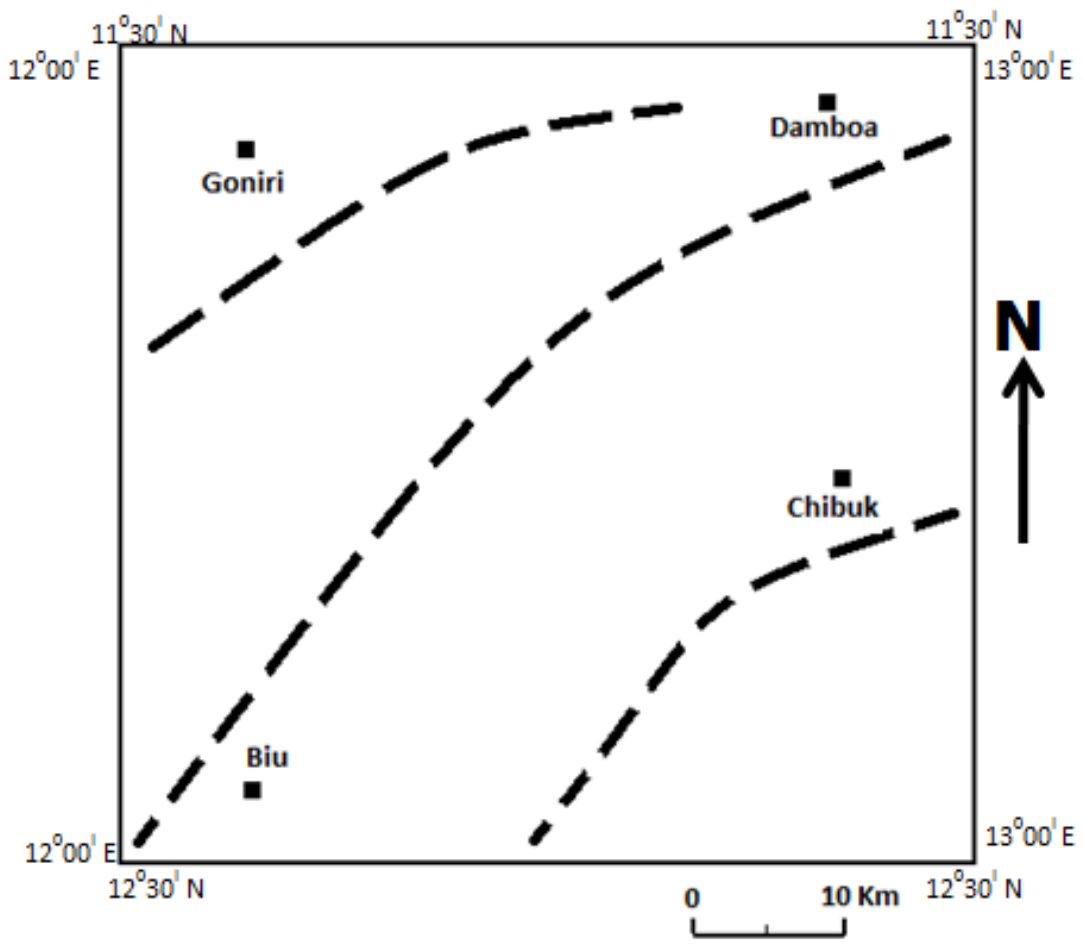

Figure4: Prominent magnetic lineaments in the study area

The trend of this magnetic anomaly coincides with the trend of the Benue Trough, and most of the inliers within the trough [2]. The trend also coincides with the main direction of the shear (mylonite) zones in the upper part of the Benue trough $[20,21,22]$ which are characterized by large magnetic anomalies as displayed by magnetic anomaly lineament around Biu, Chibuk, Goniri and Damboa. These anomalies are of sufficient prominence in length to suggest that they are probably signatures of regional features representing major tectonic trends, because they cut across both basement and sedimentary cover. Also another authors suggested the existence of widespread NE-SW trending structures and lineaments in the Benue trough [23]. The trend of these magnetic anomalies also coincides with the major direction of fracture zone (NE-SW) in the middle Benue trough [3]; the Cameroon rift valley; the middle Niger lineament and the Chad and Congo basins. 


\subsection{Spectral Analysis}

Three NW-SE profiles, K-K ${ }^{1}, L-L^{1}$ and M-M ${ }^{1}$ selectedin the study area (Fig. 4) were subjected to spectral analysis. These profiles passed through Damboa, Chibuk and Biu towns. The power spectrum curves obtained for the profiles are presented in Fig.5. The linear segment from the low frequency portion of the spectrum, representing contributions from the deep-seated causative bodies could be drawn from the graph.

Sedimentary rocks generally have very weak magnetic susceptibility compared to basement rocks. Therefore, variation of the magnetic intensities over sedimentary basins is considered to originate from (1) basement structure, (2) intrusive and extrusive volcanic bodies within and/or beneath the basin and (3) occasionally in variation of susceptibilities within the basement [24]. A variety of methods have been used for determining depth estimates from magnetic data $[25,26]$. For this study the spectral analysis method was used because of its ability to filter all the noise from the data and no information is lost in the process.
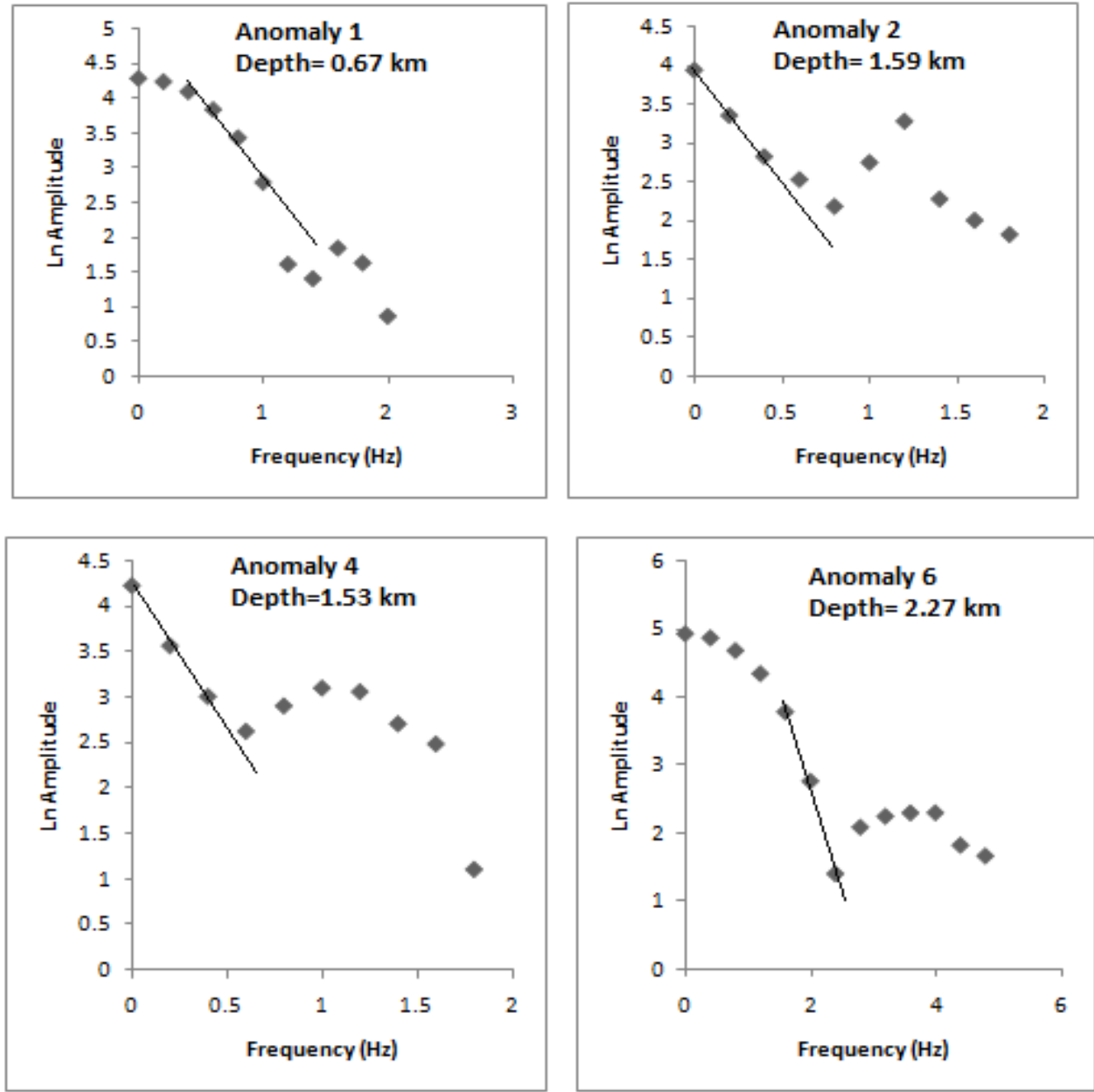

Figure5: Representative of energy spectrum on the profile within the study area

Consequently, the gradient of the linear segment was evaluated and the depth to the basement was calculated using the equation according to Spector and Grant, (1970) [14], given as $\mathrm{Z}=\mathrm{ML} / 2 \pi$

Where, $\mathrm{Z}=$ depth to basement

$\mathrm{M}=$ gradient of the linear segment

$\mathrm{L}=$ length of the cross section of the anomaly.

The depth to basement obtained ranges from $0.67 \mathrm{~km}$ to $2.27 \mathrm{~km}$. The average depths determined for each profile from spectral analysis are given in Table 1. 
Table 1: Depth obtained from spectral analysis

\begin{tabular}{|c|l|r|r|r|}
\hline \multicolumn{1}{|c|}{ Profile name } & \multicolumn{1}{|c|}{ Profile direction } & \multicolumn{1}{c|}{ Anomaly } & \multicolumn{1}{c|}{ Gradients } & \multicolumn{1}{c|}{ Depth } \\
\hline \multirow{2}{*}{$\begin{array}{c}\text { K-K } \\
\text { Along Damboa }\end{array}$} & NW-SE & 1 & 1.0509 & 0.6689 \\
\cline { 2 - 5 } & NW-SE & 2 & 2.3249 & 1.5918 \\
\cline { 2 - 5 } & NW-SE & 3 & 1.763 & 1.3467 \\
\hline \multirow{2}{*}{$\begin{array}{c}\text { L-L } \\
\text { (Goniri-Chibuk) }\end{array}$} & NW-SE & 4 & 2.6741 & 1.5319 \\
\cline { 2 - 5 } & NW-SE & 5 & 2.77984 & 2.1234 \\
\cline { 2 - 5 } & NW-SE & 6 & 2.9732 & 2.2711 \\
\cline { 2 - 5 } & NW-SE & 7 & 1.64222 & 0.9408 \\
\hline \multirow{3}{*}{ M-M ${ }^{1}$ (Along Biu) } & NW-SE & 8 & 3.6675 & 2.1011 \\
\cline { 2 - 5 } & NW-SE & 9 & 0.8894 & 0.6793 \\
\cline { 2 - 5 } & NW-SE & 10 & 0.7984 & 0.4574 \\
\hline
\end{tabular}

\section{3:2D Modeling and Interpretation}

Both negative and positive anomalies are observed during magnetic interpretation. The models of the anomalies are plotted using the 2.0 dimension program. Theaverage lateral extension used for each model is 10 km (Figs.6-8).

In general, the wholemodelshaveten principal anomalies.At model section along profile $\mathrm{K}-\mathrm{K}^{1}$, there are three prominent anomalies with variation in depth to basement. Also, the model sections for profile L-L and M$\mathrm{M}^{\mathrm{l}}$ have five and two prominent anomalies respectively.

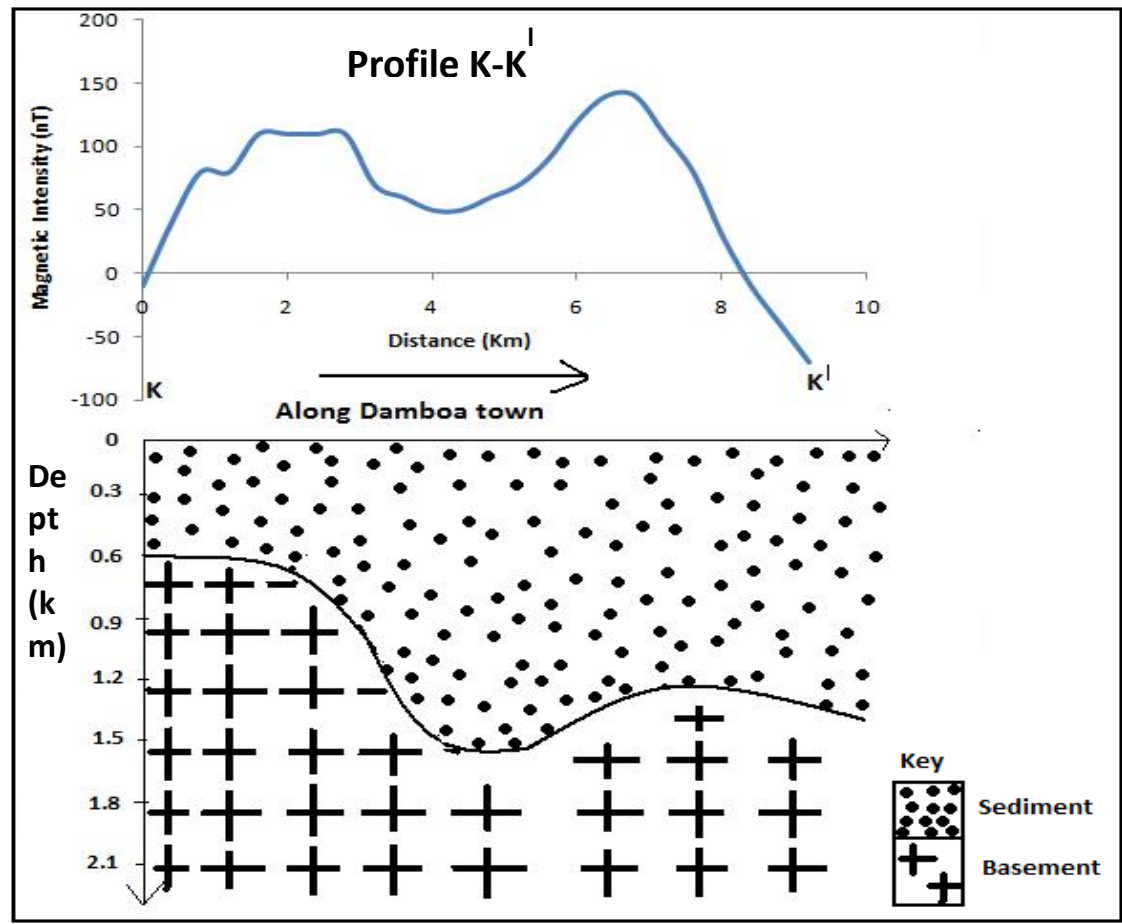

Fig.6: Geological model section along Profile $\mathrm{K}-\mathrm{K}^{1}$ 


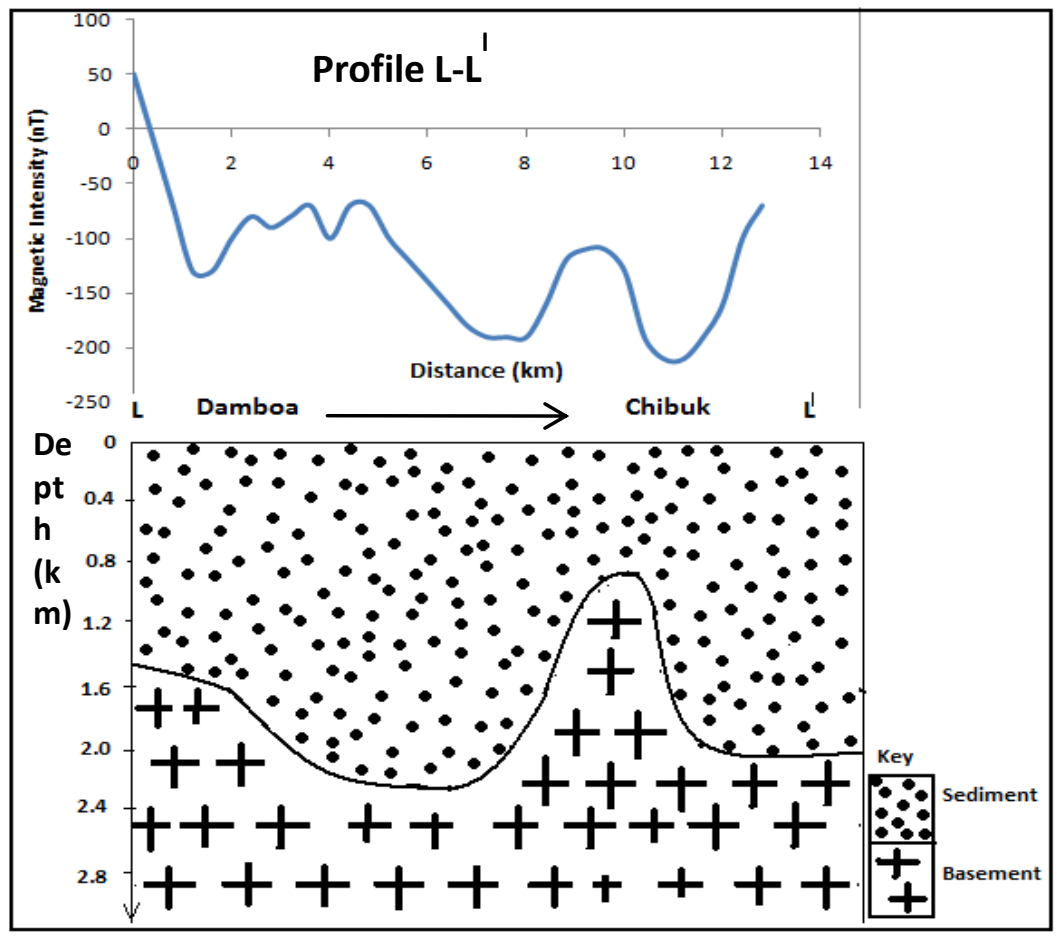

Fig.7: Geological model section along Profile L-L

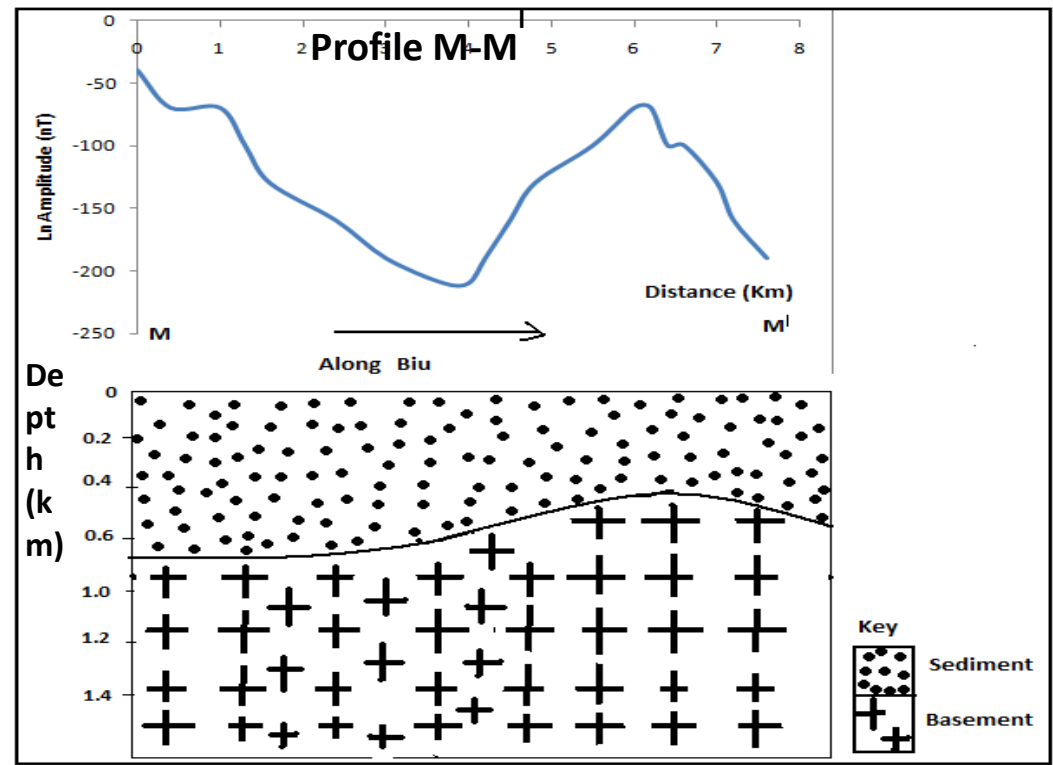

Figure8: Geological model section along Profile M-M ${ }^{1}$

\section{4: StructuralImplications}

The geodynamic process that led to the formation of the Benue Trough is still debated. Most workers $[3,27,2829,30,31]$, however, do agree that the initial stages of rifting that eventually led to the formation of the trough were related to the opening of the Atlantic Ocean and theseparation of Africa from South America. An author believed that the initial stages of rifting between Africa and South America and the opening of the South Atlantic Ocean are related to a Lower Cretaceous super plume [31].

Accordingly, two major mantle plumes of contrasting features, the St. Helena and Tristan da Cunha appear to have exerted a fundamental control on the process of continental break-up. The Trista da Cunha plume gave rise to the Mesozoic Parana volcanism in Brazil $[32,33]$. This volcanism is broadlycontemporaneous with the first magmatic period (147-106 Ma) that has been defined in the northern Benue Trough [4], of which the study area is part. According to some authors, from about $70 \mathrm{Ma}$, magmatism of the Cameroon line replaced the 
Mesozoic to early Cenozoicmagmatism of the Benue Trough [4]. Another author suggested that, based on the remarkable ' $\mathrm{Y}$ ' shape and size similarities between the Benue trough and the Cameroon line, that they were related to a common hot-zone in the asthenosphere, over which the African plate moved, and, therefore, they form a migrating rift system [29].

Moreso, some authors used geochemical evidence to show that a mantle plume, over which the African plate migrated, has controlled magma generation in the Benue trough and in the Cameroon line [4]. If the major magnetic anomaly observed in the area of study is caused bymafic rocks, as the interpretation suggests, then the area represents an old rift zone where a diapiric intrusion of mantle originating rock caused by the activity of a plume rose to the lower crust and upper crust [34]. This rising diapir would then also have thermally expanded the lithosphere. After the emplacementof the mafic rocks, slow cooling probably resulted in thermal contraction and subsequent subsidence and sedimentation.

The results of this study, therefore suggest that the magnetic lineaments observed in the area are trending in the same direction (NE-SW) as most of the known structures in and around the Benue Trough and Chad Basin. It is indeed most likely to bea magmatic failed rift that is buried at about $8 \mathrm{~km}$ depth within the Gongola arm of the trough[34]. This 'aborted' structure indicatesthatmagmatism in the Benue Trough could have been produced bya weak plume and that is probably the reason why the volcanics did not reach the surface. Sedimentation subsequent to rifting has completely covered them and the apparent lack of continuing intense surface volcanism in the trough follows from this assertion. The authors are therefore in support of the hypotheses on the origin of the trough that suggests that the R-R-R triple junction of the Benue Trough arose from doming and rifting associated with the rise of a mantle plume [28].

\section{Conclusions}

A composite magnetic map of some parts of Upper Benue Trough and Southern Chad Basin, Nigeria compiled from aeromagnetic maps highlights a prominent NE-SW magnetic low in the area. Magnetic depth estimates along three selected profiles across the anomalies using the spectral analysis show that the prominent NE-SW anomaly is probably caused by intra basement intrusives of high magnetic susceptibility, at depths which lie predominantly between 0.67 and $2.27 \mathrm{~km}$. Twodimensionalmodeling of the profiles shows clearly the variation of the sedimentary thickness within the study area. Thus, the basement which is directly underlain by a thick sedimentary cover of about 2.27 kmhas been masked bythese sediments. The presence of a mafic igneous intrusion, possibly in some parts of the study area before being covered by sediments of the trough, suggests that deep fissures exist in the crust beneath thetrough, thus supporting the view that the trough is a rift structure.

\section{References}

[1]. Genik, G. J. (1992). Regional framework, structural and petroleum aspects of rift basins in Niger, Chad and the Central African Republic (C.A.R.). Tectonophysics, 213:169-185.

[2]. Benkhelil, J. (1989). The origin and evolution of the Cretaceous Benue trough (Nigeria). Journal of African Earth Sciences 6: 251282 .

[3]. Wright, J.B. (1968). South Atlantic and Continental drift and the Benue Trough.Tectonophysics , 213: $203-225$.

[4]. Coulon, C., Vidal, P., Dupuy, C., Popoff, M., Maluski, H and Hermite, D. (1996). The Mesozoic to early Cenozoicmagmatism of the Benue trough (Nigeria); geochemical evidence for the involvement of the St Helena plume. Journal of Petrology, 37 (6): $1341-$ 1358 .

[5]. Barber, W. (1965). Pressure water in the Chad Formation of Borno and Dikwa Emirates, Northeastern Nigeria. Geological Survey of Nigeria Bulletin, No.35: 138.

[6]. Okosun, E.A. (1995). Review of Geology of Bornu Basin. Journal of mining and Geology, 31 (2): $113-172$

[7]. Sharma P. V, (1987). Magnetic method applied to mineral exploration. Ore Geology, 2: $323-357$.

[8]. Fairhead, J.D. and Binks, R.M. (1991). Differential opening of the west central and south Atlantic oceans and the opening of the West Africa rift system. Tectonophysics, 187:191-203.

[9]. Binks, R.M. and Fairhead, J.D. (1992). A plate tectonic setting for the Mesozoic rifts of the Westand Central Africa.Tectonophysics, 213: 41-151.

[10]. Nwankwo, C.N, Ekine, A.S; and Nwosu L.I. (2009). Estimation of Heat Flow variation in the Chad Basin Nigeria. Journal of Applied Sciences Environmental, 13 (1): 73 - 80.

[11]. Hall, D.H., 1974. Long-wavelength aeromagnetic anomalies and deep crustal magnetisation in Manitoba and northwestern Ontario, Canada. Journal of Geophysics 40, 403-430.

[12]. Ajakaiye, D. E., Hall, D. H., and Millar, T. W. (1985). Interpretation of aeromagnetic data acrossthe central crystalline shield area of Nigeria. Geophysical Journal, 83:.503-517.

[13]. Spector, A., and Grant, F. S. (1970). Statistical models for interpretation of aeromagneticdata. Geophysics 35: 293-302.

[14]. Ofoegbu, C.O., 1988. An aeromagnetic study of part of the upper Benue trough, Nigeria.Journal of African Earth Science, 6, pp777-790.

[15]. Onwuemesi, A.G. (1997). One Dimensional Spectral Analysis of Aeromagnetic Anomalies and Curie Depthsotherm in the Anambra Basin of Nigeria. Journal of Geodynamics, 23 (2): 95-107.

[16]. Abubakar, Y.I.; Umego, M.N. and Ojo, S.B.(2010). Evolution of GongolaBasinUpperBenueTroughNortheastern Nigeria. Asia Journal Earth Science, 3: 62-72.

[17]. Anakwuba, E.K, Onwuemesi, A.G., Chinwuko, A.I and Onuba, L.N., (2011). The interpretation of aeromagnetic anomalies over Maiduguri-Dikwa depression, Cha Basin Nigeria: A structural view. Archives of Applied Science Research, 3 (4), $499-508$.

[18]. Chinwuko, A. I., Onwuemesi, A.G., Anakwuba, E.K. and Nwokeabia, N.C. (2012). Interpretation of aeromagnetic anomalies over parts of Upper Benue Trough and Southern Chad Basin, Nigeria. Advances in Applied Science Research, 3(3), $1757-1766$. 
[19]. Kivior, I and Boyd, D. (1998). Interpretation of the aeromagnetic experimental survey in the Eromanga/Cooper Basin. Can.J. Explor. Geophys. 34 (1 and 2), 58-66.

[20]. ELF Nig. LTD. (1985). Structural interpretation of the Benue trough and the Bornu basin. Unpublished report,Lagos pp.59.

[21]. Ajakaiye, D.E., Hall, D.H., Millar, T.W., Verheijen, P.J.T., Awad, M.B.,andOjo, S.B.(1986.)Anomalies and tectonictrends in and around the Benue trough,Nigeria.Nature, 319: 582-584.

[22]. Benkhelil, J., Dainelli, P., Ponsard, J.F., Popoff, M., and Saugy, L. (1988). The Benue Trough:wrench fault related basin, on the border of the equatorial Atlantic. In: Manspeizer, W. (Ed.), Triassic-Jurassic Rifting, Continental Break-up and the Origin of the Atlantic Ocean and Passive Margins, 1988. (Ed.), Developments in Geotectonics22. Elsevier, Amsterdam, pp. 789-819.

[23]. Cratchley, C.R., Louis, P AndAjakaiye, D.E., 1984. Geophysical and geological evidence for the Benue-Chad Basin Cretaceous rift valley systems and its tectonic implications. Journal of African Earth Sciences 2, 141-150.

[24]. Behrendt, J.C., and Klitgord, K.D.(1980). High-sensitivityaeromagneticsurveyof the USAtlanticcontinentalmargin.Geophysics 45, 1813-1846.

[25]. Peters, L. (1949). The direct approach to magnetic interpretation and its practical application.Geophysics 14: $290-320$.

[26]. Vacquier, V., Steenland, N.C., Henderson, R.G and Zietz, I., 1951. Interpretation` of aeromagnetic maps.Geol.Society America. Memoir, 47: 151 .

[27]. Cratchley, C.R and Jones,J.P.(1965). An interpretation of the geology and gravityanomalies ofthe Benue valley,Nigeria.Overseas geol. Surv.Geophys. Paper 9, 1-28.

[28]. Olade, M.A. (1975). Evolution of Nigeria's Benue trough (Aulacogen): A tectonic model. Geological Magazine 112: $575-581$.

[29]. Fitton, J.G. (1980). The Benue trough and Cameroon line a migrating rift system in West Africa. Earth and Planetary Science Letters, 51: 132-138.

[30]. Fairhead, J.D.(1988). Mesozoic plate tectonic reconstruction of the central SouthAtlanticOcean: the role of theWestand Central African rift system.Tectonophysics, 155: 1181-1191.

[31]. Wilson, M. (1992). Magmatism and continental rifting during the opening of the south Atlantic ocean: a consequence of Lower Cretaceous super plume activity? In: Storey, B.C., Alabaster, T., Pankhurst, R.J. (Eds.), Magmatism and the Causes of Continental Break- up. Geological Societyof London, Special Publication No. 68, pp. 241-255.

[32]. Renne, P.R., Ernesto, M., Pacca, I.G., Coe, R.S., Glen, J.M., Prevot, M., and Perrin, M. (1992). The age of Parana flood vol canism. Rifting of Gwondwanaland, and the Jurassic-Cretaceous boundary. Science, 258: 975-979.

[33]. Turner, S., Regelous, M., Kelly, S., Hawkesworth, C and Mantovani, M. (1994). Magmatism and continental breakup in the South Atlantic: high precision 40Ar-39Ar geochronology. Earth and Planetary Science Letters, 121: 333-348.

[34]. Shemanga, E.M., Ajayib, C.O. and Jacobya, , W.R.(2001). A magmatic failed riftbeneaththeGongola arm of theupper Benue trough, Nigeria. Journal of Geodynamics, 32: 355-371 